SULUH Jurnal Bimbingan Konseling, April 2017, Volume 3 Nomor 1 (26-31)

http://jurnal.umpalangkaraya.ac.id/ejurnal/suluh

\title{
EFEKTIVITAS PELATIHAN BERCERITA DENGAN MENGGUNAKAN MEDIA BONEKA TANGAN UNTUK MENINGKATKAN KEMAMPUAN BERKOMUNIKASI VERBAL PESERTA DIDIK RA MAWADDAH PALANGKA RAYA
}

\author{
Oleh
}

Eni Lidya Sari, Asep Solikin

\begin{abstract}
ABSTRAK
Penelitian ini bertujuan untuk mengetahui efektivitas pelatihan bercerita dengan menggunakan media boneka tangan untuk meningkatkan kemampuan berkomunikasi verbal peserta didik kelompok B di RA Mawaddah Palangka Raya.. Metode yang digunakan dalam penelitian ini adalah pre eksperimental design dengan pendekatan one group pretest posttest desaign. Populasi dalam penelitian ini adalah seluruh peserta didik kelompok B yang terdiri dari 4 kelas yaitu sebanyak 67 peserta didik. Jumlah sampel sebanyak 8 peserta didik. Pengambilan sampel dengan menggunakan purposive sampling. Teknik pengumpulan data berupa observasi, wawancara dan dokumentasi. Dalam menganalisis data menggunakan rumus uji-T (One Sample Test) sistem penghitungan menggunakan bantuan program software SPSS (Statistick package sosial science) under windows versi 19.00 .

Hasil penelitian terdapat peserta didik yang mengalami kesulitan dalam berkomunikasi verbal ditandai kesulitan dalam menyampaikan informasi ketika berkomunikasi sehingga lawan bicara tidak memahami maksud yang disampaikannya, pelatihan bercerita dengan menggunakan media boneka tangan efektif untuk meningkatkan kemampuan berkomunikasi verbal pada peserta didik kelompok B terbukti dengan $t$ tabel $<$ dari $t$ hitung $(1,753<24,975)$ yang artinya pelatihan bercerita dengan media boneka tangan dapat meningkatkan kemampuan berkomunikasi peserta didik di RA Mawaddah Palangka Raya
\end{abstract}

(C) Universitas Muhammadiyah Palangkaraya

\section{Kata Kunci: Media Boneka Tangan, Berkomunikasi Verbal}

\section{PENDAHULUAN}

Sekolah merupakan lembaga formal yang berfungsi membantu khususnya orang tua dalam memberikan pendidikan kepada anak-anak mereka. Sekolah memberikan pengetahuan, keterampilan, kemandirian dan sikap kepada anak didiknya secara lengkap sesuai dengan yang mereka butuhkan. Mendapatkan pendidikan merupakan hak setiap individu, termasuk juga anak usia dini. Landasan yuridis mengenai konsep dasar pendidikan anak usia dini tertuang dalam UU No. 23 tahun 2002 Pasal 9 Ayat 1 dikutip oleh Panggabean (2013: 4-5) yang berbunyi setiap anak 
berhak memperoleh pendidikan dan pengajaran dalam rangka pengembangan pribadinya dan tingkat kecerdasannya sesuai dengan minat dan bakatnya.

Kemampuan berkomunikasi erat kaitannya dengan bahasa, bahasa sebagai alat komunikasi merupakan sarana yang sangat penting dalam kehidupan anak untuk bersosialisasi dan berkomunikasi dengan teman atau orang di sekitar lingkungannya seperti pendapat Badudu dalam (Utariani, dkk, 2014: 2) yang menyatakan bahwa bahasa adalah alat penghubung atau komunikasi antara anggota masyarakat yang terdiri dari individu-individu yang menyatakan pikiran, perasaan, dan keinginannya. Agiris dalam (Nurrohim dan Anatan, 2009: 3) komunikasi adalah suatu proses dimana seseorang, kelompok, atau organisasi (sender) mengirimkan informasi (massage) pada orang lain, kelompok, atau organisasi (receiver). Nursalim (2013: 1) menyatakan komunikasi adalah proses penerimaan dan penyampaian pesan dan pemahaman pada waktu yang sama tanpa ada awal dan akhir, sedangkan menurut Astuti, dkk (2013: 2) komunikasi adalah peristiwa sosial, peristiwa yang terjadi ketika manusia berinteraksi dengan orang lain. Majid (2014: 285) yang menyatakan bahwa "Komunikasi merupakan suatu proses yang melibatkan dua orang atau lebih yang di dalamnya terjadi pertukaran informasi dalam rangka mencapai tujuan tertentu

Kemampuan berkomunikasi pada anak sesuai rentang usia 4-6 tahun menurut Sujiono (2009: 159) yaitu:
1. Menyebutkan nama-nama huruf/ suara.

2. Menunjukkan minat yang tinggi dalam bermain peran (menciptakan kembali pekerjaan orang dewasa, menggunakan kostum dan alat-alat pentas)

3. Berkaitan dengan permainan sosial, biasanya mampu bekerjasama, mempraktekan, bermusyawarah (bermain purapura dengan menggunakan peran orang dewasa yang realistis atau nyata).

4. Menunjukkan minat menulis dan membaca kata-kata atau kalimat.

Hurlock dalam (Rosalina 2010: 9) mengatakan bahwa Anak seharusnya sudah memiliki sekitar 20 kata pada usia 18 bulan, dan sekitar 50 kata atau penggalan kata pada usia 24 bulan. Apabila anak mengalami kesulitan dalam menyampaikan keinginannya kepada orang lain, dikhawatirkan akan berpengaruh pada perkembangan kepribadian anak, seperti pendapat Syaodih dalam (Utariani, dkk, 2014: 4) bahwa adanya hambatan dalam perkembangan bahasa anak membuat anak merasa tidak diterima oleh temantemannya, anak menjadi minder, tidak percaya diri dan tidak memiliki keberanian untuk berbuat.

Berdasarkan pengamatan awal peneliti pada anak kelompok B3 di RA Mawaddah Palangka Raya pada Jumat, 12 Februari 2016 ditemukan beberapa permasalahan dalam berkomunikasi pada peserta didik di lapangan antara lain anak tidak mampu menyebutkan nama, tidak mampu menyebutkan huruf ataupun suara yang diperdengarkan oleh orang lain. Anak berbicara namun 
kurang dipahami oleh teman sebayanya, anak kesulitan dalam mengemukaan pendapat, pikiran dan kehendaknya, kesulitan menceritakan pengalaman secara sederhana dan mengulang kalimat yang disampaikan orang lain, anak ragu-ragu menjawab bila ada pertanyaan dari guru serta tidak percaya diri ketika diminta berbicara di depan kelas.

Hasil wawancara tidak terstruktur yang dilakukan peneliti dengan wali kelas kelompok B3, Ibu Zainah, A. Ma pada hari Senin, 15 Februari 2016 pukul 09.15 WIB (foto terlampir) menyatakan bahwa terkait dengan penggunaan bahasa dalam keseharian anak di sekolah tentunya perlu mendapatkan perhatian yang serius agar mampu memberikan pemahaman yang lebih mendalam sejak dini tentang bagaimana berbicara dengan bahasa yang baik, mengingat berbicara merupakan bentuk komunikasi yang paling efektif, penggunaannya paling luas dan paling penting sebagai bentuk komunikasi, maka pembelajaran berbahasa harus dimulai sejak dini walaupun tidak harus sesuai dengan kaidah Bahasa Indonesia.

Tahapan-tahapan yang dapat digunakan oleh guru dalam melatih dan mengembangkan kemampuan berkomunikasi pada anak dapat dimulai dari mengenalkan beberapa kata atau kalimat sederhana terlebih dahulu. Dengan mengenalkan beberapa katakata sederhana dan sering mengajak anak untuk berkomunikasi, diharapkan kemampuan anak dalam berkomunikasi bisa menjadi lebih baik. Pada hakikatnya kegiatan pembelajaran merupakan proses komunikasi, guru bertindak sebagai komunikator yang bertugas menyampaikan pesan pembelajaran kepada penerima pesan yaitu peserta didik. Namun dalam proses pembelajaran seyogyanya guru tidak memakai cara yang monoton hanya berdiri di depan kelas untuk bercerita tanpa ada variasi dalam pembelajaran, hal tersebut dapat menyebabkan anak kurang tertarik, jenuh dan bosan karena pembelajaran lebih banyak didominasi guru tanpa melibatkan anak secara aktif.

Agar pesan pembelajaran yang disampaikan guru dapat diterima dengan baik oleh anak maka dalam proses komunikasi pembelajaran selain suara atau vokal diperlukan wahana penyalur pesan yang disebut media pembelajaran. Dengan pemilihan media pembelajaran yang tepat, diharapkan dapat mengajak anak berlatih berkomunikasi dengan lebih aktif, ujaran yang masih kurang jelas bisa diperbaiki, dan perasaan takut pada anak dalam menyampaikan keinginannya bisa berkurang. Dalam kegiatan pembelajaran, ada banyak media yang bisa digunakan guru dalam proses pembelajaran, salah satunya yaitu boneka tangan.

Menurut Daryanto dalam (Marini, dkk, 2015: 4), boneka tangan adalah benda tiruan dari bentuk manusia atau binatang yang dimainkan dengan satu tangan. Sulianto (2014: 2) menyebutkan dinamakan boneka tangan karena para pemain (guru, siswa, atau orang tua) memainkannya dengan cara memasukkan telapak tangan mereka ke dalam boneka. Hal ini selaras dengan pendapat Gunarti dalam (Sulianto 2014: 
2) tentang definisi dan gambaran boneka tangan. Menurut pendapatnya boneka tangan adalah boneka yang ukurannya lebih besar dari boneka jari dan bisa dimasukkan ke tangan, jari tangan bisa dijadikan pendukung gerakan tangan dan kepala boneka.

Berdasarkan uraian di atas, maka dalam peneliti tertarik untuk mengangkat permasalahan yang berkaitan dengan proses pembelajaran dalam upaya meningkatkan keterampilan berkomunikasi verbal pada peserta didik di RA Mawaddah dengan menggunakan media boneka tangan khususnya untuk anak kelompok B. Untuk itu peneliti meneliti dengan judul penelitian Efektivitas Pelatihan Bercerita Menggunakan Media Boneka Tangan Untuk Meningkatkan Kemampuan Berkomunikasi Verbal Peserta Didik RA Mawaddah Palangka Raya.

\section{METODE PENELITIAN}

Desain penelitian yang akan digunakan dalam penelitian ini adalah pre eksperimental design dengan pendekatan one group pretest posttest desaign. Menurut Sugiyono (2014:109) mengapa dinamakan pre-eksperimental design karena masih terdapat variable luar yang ikut berpengaruh terhadap terbentuknya variable dependen. Hariyanti dan Muhari (2013:3-4) mendefinisikan desain penelitian pre eksperimen dengan pendekatan one group pretest posttest desaign adalah eksperimen yang dilakukan pada satu kelompok saja tanpa adanya kelompok pembanding, sehingga dalam penelitian ini diasumsikan bahwa perbedaan antara pengukuran awal dan akhir merupakan efek dari adanya sebuah perlakuan.

\section{Gambar 1}

Bentuk bagan desain Penelitian

\begin{tabular}{|ccc|}
\hline $\mathrm{O} 1$ & $\mathrm{X}$ & $\mathrm{O} 2$ \\
Pretest & Treatment & Posttest \\
\hline
\end{tabular}

populasi penelitiannya peserta didik kelompok B RA Mawaddah Palangka Raya yang berjumlah 67 orang. Dalam penelitian ini teknik pengmabilan sampel yang digunakan adalah non probability sampling dengan menggunakan purposive sampling, instrumen penelitin yang digunakan adalah skala, observasi, wawancara.

\section{HASIL DAN PEMBAHASAN}

Secara kuantitatif peningkatan kemampuan komunikasi siswa bisa dilihat dari perbandingan nilai skor Pretest dan Posttest yang diperoleh, Berikut rincian perolehan skor Pretest dan Posttest yang dilakukan peneliti selama proses penelitian.

\section{Tabel 1}

Hasil Analisis Pretest dan Postest

\begin{tabular}{cllll}
\hline \multirow{2}{*}{ No } & $\begin{array}{l}\text { Inisial } \\
\text { Siswa }\end{array}$ & $\begin{array}{l}\text { Skor Tes } \\
\text { Pretest }\end{array}$ & $\begin{array}{l}\text { Gaint } \\
\text { Pktest }\end{array}$ \\
\hline 1 & DK & $\mathbf{3 2}$ & $\mathbf{4 2}$ & $\mathbf{1 0}$ \\
2 & MRP & $\mathbf{3 6}$ & $\mathbf{4 2}$ & $\mathbf{6}$ \\
3 & MF & $\mathbf{2 5}$ & $\mathbf{3 2}$ & $\mathbf{7}$ \\
4 & AZ & $\mathbf{2 6}$ & $\mathbf{3 6}$ & $\mathbf{1 0}$ \\
5 & NH & $\mathbf{2 8}$ & $\mathbf{3 7}$ & $\mathbf{9}$ \\
6 & HAR & $\mathbf{3 1}$ & $\mathbf{4 2}$ & $\mathbf{1 1}$ \\
7 & SS & $\mathbf{3 3}$ & $\mathbf{3 9}$ & $\mathbf{6}$ \\
\hline
\end{tabular}




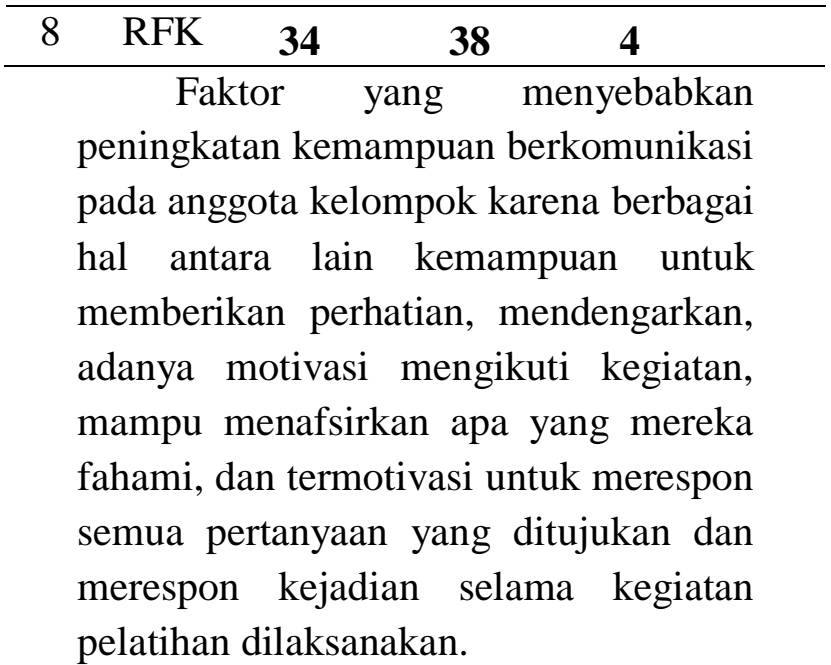

Alasan mengapa peserta didik mengalami peningkatannya yang berbeda dikarenakan kemampuan yang tidak sama antara satu dan lainnya. Tingkat konsentrasi pada peserta didik juga mempengaruhi hasil dari skor tersebut mengingat bahasa merupakan salah satu elemen yang terpenting dalam perkembangan berpikir dan bahasa pula yang dapat membedakan manusia dari mahluk lainnya sehingga sebagai alat komunikasi, bahasa merupakan sarana yang sangat penting dalam kehidupan anak.

Pada masa akhir usia taman kanak-kanak, anak umumnya sudah mampu berkata-kata sederhana dan berbahasa sederhana, cara bicara mereka telah lancar, dapat dimengerti dan cukup mengikuti tata bahasa walaupun masih banyak melakukan kesalahan berbahasa. Dalam berkomunikasi, anak belajar mengutarakan apa yang ada dalam fikirannya dalam bentuk kata-kata untuk berinteraksi dengan lingkungan dan orang yang ada disekitarnya.

Dari interaksi dengan lingkungan itulah maka kemampuan berkomunikasinya akan menjadi berkembang. Pada anak dengan kemampuan berkomunikasi verbal yang kurang, akan mengalami kendala dalam berkomunikasi, anak kurang berhasil dalam menyampaikan informasi ketika berkomunikasi sehingga lawan bicara tidak memahami maksud yang disampaikannya.

Anak yang memiliki kemampuan berkomunikasi sedang terbentuk dari hasil belajar di lingkungan sekitar dengan berbagai cara, bisa melalui imitasi (meniru) atau dari kemampuan anak dalam mendengar dan menyimak suatu percakapan yang dilakukan orang lain. Faktor-faktor yang menyebabkan komunikasi bisa berjalan efektif atau tidak dipengaruhi oleh beberapa hal yaitu sender (pengirim informasi), receiver (penerima informasi), informasi, feedback, dan media

\section{KESIMPULAN}

Kemampuan berkomunikasi verbal pada peserta didik kelompok B di RA Mawaddah Palangka Raya pada umumnya baik, namun ditemui beberapa peserta didik yang mengalami kesulitan dalam berkomunikasi verbal, hal ini terlihat dari hasil observasi dan hasil wawancara yang dilakukan pada kepala sekolah, guru kelas dan orang tua peserta didik yang bersangkutan. Kemampuan berkomunikasi verbal peserta didik di lapangan antara lain anak masih ragu-ragu dalam berbicara, kesulitan dalam menyebutkan nama sendiri, nama orang lain dan nama benda-benda yang ada di sekitar, kesulitan menyampaikan gagasan, pikiran dan kehendak kepada guru dan 
temannya, tidak percaya diri saat diminta untuk berbicara dengan guru atau teman-temannya. Hasil yang diperoleh dalam penelitian ini menunjukkan bahwa kegiatan pelatihan bercerita dengan mengunakan media boneka tangan efektif dalam upaya meningkatkan kemampuan bekomunikasi verbal peserta didik dengan diperoleh penambahan skor dari 8 (delapan) peserta didik yang menjadi subyek penelitian.

\section{DAFTAR PUSTAKA}

Astuti, Anita Dewi, dkk. 2013. Model layanan BK Kelompok Teknik Permainan (Games) Untuk Meningkatkan Keterampilan Komunikasi Interpersonal Siswa. Jurnal Bimbingan Konseling. ISSN 2252-6889

Hariyanti, Desi Dwi dan Muhari. 2013. Penerapan Konseling Kelompok Rational Emotive Behavior Untuk Meningkatkan Motivasi Belajar Siswa Kelas VIII G SMP Yayasan Pendidikan 17 Surabaya. Jurnal BK Unesa. Volume 01 nomor 01.

Majid, Abdul.2014. Strategi Pembelajaran.Bandung:PT Remaja Rosdakarya

Marini, Ketut, dkk. 2015. Penerapan Metode Bercerita Berbantuan Media Boneka Tangan Untuk Meningkatkan Keterampilan Berbicara Pada Anak Kelompok B3. e-Journal PG PAUD Universitas Pendidikan Ganesha Jurusan PG-PAUD . Volume 3 No. 1

Nurrohim, Hassa dan Anatan, Lina. 2009. Efektivitas Komunikasi Dalam Organisasi. Jurnal Managemen. Vol. 7, No 4

Nursalim, Mochamad. 2013. Pengembangan Media Bimbingan dan Konseling. Jakarta: Akademia Permata

Panggabean, Ance Juliet. 2013. Suatu Kajian Tentang Pengetahuan Dasar dan Kegiatan Keterampilan Seni Musik Untuk Mengembangkan Potensi Musik Anak Usia Dini. Jurnal Bimbingan dan Konseling. ISSN 0853-0203

Rosalina, Anita, dkk. 2010. Peranan Orangtua Dalam Dongeng Sebelum Tidur Untuk Optimalisasi Kemampuan Berkomunikasi Anak Usia Dini. Jurnal Psycho Idea. ISSN 16931076

Sugiyono. 2013. Metode Penelitian Pendidikan Pendekatan Kuantitatif Kualitatif, Dan $R \& D$. Bandung: Alfabeta

Sujiono, Yuliani Nurani. 2009. Konsep Dasar Pendidikan Anak Usia Dini. Jakarta: PT Indeks

Sulianto, Joko,dkk. 2014. Media Boneka Tangan Dalam Metode Berceritera Untuk Menanamkan Karakter Positif Kepada Siswa Sekolah Dasar. Jurnal pendidikan. Volume 15 nomorz.

Utariani, Ni Komang, dkk. 2014. Penerapan Metode Bercerita Berbantuan Media Boneka Jari Untuk Meningkatkan Kemampuan Berbahasa Anak TK Kelompok A. e-Journal PG PAUD Universitas Pendidikan Ganesha. Volume 2 Nomor 1

Walgito, Bimo. 2010. Bimbingan + Konseling (studi \& karir). Yogyakarta. CV Andi Offset 